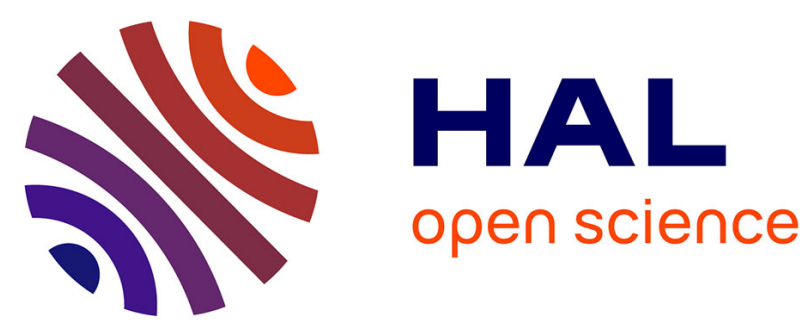

\title{
Evidence for long-term prevalence of cucumber vein yellowing virus in Sudan and genetic variation of the virus in Sudan and the Mediterranean Basin
}

Cecile Desbiez, P. Caciagli, Catherine Wipf-Scheibel, Pauline Millot, L. Ruiz, D. Marian, Gasim Dafalla, Hervé Lecoq

\section{To cite this version:}

Cecile Desbiez, P. Caciagli, Catherine Wipf-Scheibel, Pauline Millot, L. Ruiz, et al.. Evidence for longterm prevalence of cucumber vein yellowing virus in Sudan and genetic variation of the virus in Sudan and the Mediterranean Basin. Plant Pathology, 2019, 68 (7), pp.1268-1275. 10.1111/ppa.13055 . hal-02306104

\section{HAL Id: hal-02306104 \\ https://hal.science/hal-02306104}

Submitted on 26 May 2020

HAL is a multi-disciplinary open access archive for the deposit and dissemination of scientific research documents, whether they are published or not. The documents may come from teaching and research institutions in France or abroad, or from public or private research centers.
L'archive ouverte pluridisciplinaire HAL, est destinée au dépôt et à la diffusion de documents scientifiques de niveau recherche, publiés ou non, émanant des établissements d'enseignement et de recherche français ou étrangers, des laboratoires publics ou privés.

\section{(ㅇ)(1) $\$$}

Distributed under a Creative Commons Attribution - NonCommercial - NoDerivatives| 4.0 
Article type: Original Article

Evidence for long-term prevalence of cucumber vein yellowing virus in Sudan and genetic variation of the virus in Sudan and the Mediterranean Basin.

C. Desbiez ${ }^{1 *}$, P. Caciagli ${ }^{2}$, C. Wipf-Scheibel ${ }^{1}$, P. Millot ${ }^{1}$, L. Ruiz ${ }^{3}$, D. Marian ${ }^{2}$, G. Dafalla ${ }^{4}$, H. Lecoq $^{1}$

${ }^{1}$ INRA, UR407, Unité de Pathologie Végétale, 84143 Montfavet cedex, France

${ }^{2}$ CNR, IPSP, 10135 Torino, Italy

${ }^{3}$ IFAPA Centro La Mojonera, IFAPA, La Mojonera 04745, Almería, Spain

${ }^{4}$ Plant Pathology Center, University of Gezira, Wad Medani, Sudan

Corresponding author: cecile.desbiez@inra.fr

Running title: genetic variation and evolution of CVYV

Keywords: Ipomovirus, CVYV, evolution, diversity, Potyviridae

This article has been accepted for publication and undergone full peer review but has not been through the copyediting, typesetting, pagination and proofreading process, which may lead to differences between this version and the Version of Record. Please cite this article as doi: 10.1111/ppa.13055

This article is protected by copyright. All rights reserved. 


\section{Abstract}

Cucumber vein yellowing virus (CVYV) is emerging throughout the Mediterranean Basin, where it causes important damages on cucumber and melon crops. It has been suggested that CVYV originated from the Middle East and has spread only recently to other areas. In this work, an isolate from Sudan was characterized and surveys performed in that country between 1992 and 2012 revealed a long-term presence of CVYV with a high molecular variability, showing that the virus has long been endemic in Sub-Saharan Africa. Comparison of the full-length sequences of $11 \mathrm{CVYV}$ isolates from different geographic origins revealed recombination events in CVYV populations from the Mediterranean Basin and the Middle East, and evidence for different selection pressures along the genome. These results shed a new light on the evolution of CVYV.

Introduction

Cucumber vein yellowing virus (CVYV), first described in 1960 in Israel (Cohen \& Nitzany, 1960), was later shown to belong to the genus Ipomovirus, containing whitefly-transmitted members of the family Potyviridae (Lecoq et al., 2000). It has a single-stranded RNA genome of about $9.7 \mathrm{~kb}$, encapsidated in flexuous filamentous particles. Contrary to the aphidtransmitted potyviruses, it encodes no helper component protein (HC-Pro) but has a duplicated P1 protein CVYV that functions as a silencing suppressor (Janssen et al., 2005). CVYV has been observed so far throughout the Middle East and the Mediterranean Basin (https://gd.eppo.int/taxon/CVYV00/reporting), but also in Sudan (Desbiez et al., 2001) and maybe in India (Ghosh \& Mukhopadhyay, 1979), but not in Eastern Asia or America (Lecoq \& Desbiez, 2012). Besides, ipomoviruses infecting cucurbits related to but distinct from CVYV have been described in diverse geographic locations: squash vein yellowing virus (SqVYV) in

This article is protected by copyright. All rights reserved. 
North and Central America (Adkins et al., 2007) as well as in Israel (Reingold et al., 2016) and coccinia mottle virus (CocMoV) in Sudan (Desbiez et al., 2016). CVYV is now spreading all over the Mediterranean Basin, in relation to the increasingly high populations of its vector Bemisia tabaci (Lecoq \& Desbiez, 2012). In the countries where it is emerging, CVYV induces important losses due to its impact on fruits, often making them unmarketable (Cuadrado et al., 2001). Synergism between CVYV and other frequent cucurbit viruses can result in enhanced symptoms and damages (Gil-Salas et al., 2012). Control measures against CVYV target mostly its vector: insect-proof covers and greenhouses, use of insecticides or biological control agents (Lecoq \& Desbiez, 2012). These methods are costly, timeconsuming, and not always applicable. Resistance to CVYV has been described in cucumber (Gil-Salas et al., 2009). Some resistance or tolerance sources have also been found in melon (Pitrat et al., 2012), but they have not yet been used commercially, and their specificity and durability have not been assessed. The genetic structure and diversity of CVYV populations characterized so far have led to suggest that CVYV originated in the Middle East and has spread quite recently in the Mediterranean Basin (Velasco et al., 2016). However, in this work, we revealed the presence of CVYV in Sudan at least since 1992, we characterized biologically one isolate (host range and virus-vector relationship), and we studied the molecular diversity of the virus in order to understand better the factors shaping its evolution and the potential impacts for virus control through breeding for resistance.

This article is protected by copyright. All rights reserved. 
Materials and methods

Sampling and biological characterization of isolate SU96-84

Isolate SU96-84 was collected in Shendi, Sudan in 1996 from a snake melon (Cucumis melo var. flexuosus) plant showing vein clearing symptoms. The sample was negative in DAS-ELISA for the presence of viruses previously known to infect cucurbits in Sudan (zucchini yellow mosaic virus, papaya ringspot virus, Sudan watermelon mosaic virus, cucurbit aphid borne yellows virus, melon rugose mosaic virus, snake melon asteroid mosaic virus, squash mosaic virus, watermelon chlorotic stunt virus) or in other parts of the world (watermelon mosaic virus, cucumber mosaic virus) (Lecoq et al., 1995, Lecoq et al., 2011, Desbiez et al., 2017, Mohammed et al., 2014, Lecoq \& Desbiez, 2012). Electron microscope observations revealed the presence of flexuous particles as well as pinwheels, suggesting the presence of a potyvirid. RNA extraction followed by RT-PCR amplification with "potyvirid" primers (see below) showed the presence of CVYV in the sample.

The biological properties of isolate SU96-84 were characterized by studying its host range and transmission by B. tabaci. For host range study, SU96-84 infected melon plants were ground in phosphate solution $\left(\mathrm{Na}_{2} \mathrm{HPO}_{4} 0.03 \mathrm{M}+\right.$ diethyldithiocarbamate $\left.0.2 \%\right)$ and used for mechanical inoculation of test plants. One month after inoculation, systemic infections were checked by back inoculation of each plant to two melon plantlets. The test was repeated twice.

Relationships with the whitefly vector

Transmission experiments were performed with CVYV isolate SU96-84 and B. tabaci whiteflies of the MEAM1 (formerly B) biotype. Whiteflies were reared and handled as described (Caciagli et al., 1995). Melon plants cv Védrantais were used both as source and

This article is protected by copyright. All rights reserved. 
test plants. Insects, both male and female, were allowed to feed during the acquisition access period (AAP) on infected plants in large cages, then transferred to test plants in groups of variable size in small cages clipped on one true leaf of the test plant. After the inoculation access period (IAP) the insects were either transferred with the cage to new test plants (serial transfer) or killed. Infectivity results obtained with more than one insect per plant were reduced to the probability of transmission by a single vector $\left(p^{\wedge}\right)$ using the maximum likelihood estimator of $p, p^{\wedge}=1-Q^{1 / k}$, where $Q$ is the observed fraction of noninfected plants and $k$ is the number of insects used per plant, assuming that the vectors act independently (Swallow, 1985).

Effect of length of AAP. Whiteflies were allowed to feed on CVYV infected plants for 4, 6, 8, $12,16,24,32$, and $48 \mathrm{~h}$, then transferred to test plants in groups of 15 insects for the $4 \mathrm{~h}$ AAP, 10 insects for the $6 \mathrm{~h}$ and 5 insects for the other AAPs tested. Insects were removed from test plants two days later.

Effect of length of IAP. After an AAP of $32 \mathrm{~h}$, insects were transferred to test plants in groups, allowed IAP of increasing length: 1.5, 3, 6, 9,12, 15, and 24 hours, and then removed from the test plants. For increasing IAPs different number of vectors per group were used: $20,10,7,5,5,5$, and 5 individuals respectively. For each IAP, 60 groups were tested, except for 1.5 and $9 \mathrm{~h}$ ( 40 groups) and $24 \mathrm{~h}$ (20 groups).

Retention of infectivity in the vector. Insects were allowed $8 \mathrm{~h}$ AAP, then transferred to test plants in groups of 15 individuals, allowed an IAP of $3 \mathrm{~h}$, and then transferred to new test plants every $3 \mathrm{~h}$ up to $15 \mathrm{~h}$ from the end of the AAP. Forty groups of insects were tested in three experiments. An experiment of massive inoculation was done, allowing insects to feed on infected plants for $8 \mathrm{~h}$ in a large cage, then removing the source plant and replacing it in the cage with three healthy plants that were replaced every 3 hours with other healthy

This article is protected by copyright. All rights reserved. 
plants for up to 24 hours. For modelling the retention of infectivity in the vector, insects were allowed $32 \mathrm{~h}$ AAP on infected plants then moved to a feeding plant not susceptible to CVYV, and from this plant moved in groups of 20 individuals to test plants at increasing times after the end of the $\operatorname{AAP}(3,6,9,12$, and $24 \mathrm{~h})$. The only exceptions were groups of 15 insects moved directly to test plants at the end of the AAP (time 0). Insects were removed from test plants after 2 days.

Prevalence and molecular variability of CVYV in Sudan

Cucurbit samples, mostly presenting mosaics, deformation, vein clearing or yellowing symptoms suggestive of virus infections (Desbiez et al., 2016; Lecoq et al., 1995, 2011) were collected in Sudan between 1992 and 2012. All samples ground in phosphate solution $\left(\mathrm{Na}_{2} \mathrm{HPO}_{4} 0.03 \mathrm{M}+\right.$ diethyldithiocarbamate $\left.0.2 \%\right)$ were stored at $-20^{\circ} \mathrm{C}$ and could be used when needed for RNA extraction and RT-PCR. Some samples were also kept as dried leaf samples on calcium chloride, either from the original sample or after mechanical inoculation on melon or zucchini squash. The presence of CVYV was tested for samples collected between 1992 and 1996 in frozen or dried samples by RT-PCR with primers CVYV-CP-5' and CVYV-CP-3' (Bananej et al., 2006) targeting a 539 nt fragment in the coat protein coding region. For samples collected after 1996, CVYV was detected on fresh samples by DAS-ELISA using a polyclonal antiserum raised against SU96-84 or a polyclonal antiserum raised against the CVYV-Esp coat protein produced in bacteria, according to Cotillon et al., 2005 (Desbiez and Lecoq, unpublished). ELISA positive samples were subsequently submitted to RT-PCR using the same primers. The amplified fragments were sent for direct sequencing to Genoscreen, France.

This article is protected by copyright. All rights reserved. 
The partial CVYV sequences obtained were compared with the sequences currently available from Europe and the Middle East (Yakoubi et al., 2007, Velasco et al., 2016). The best substitution model was determined with MEGA 6.0. Distance and maximum likelihood trees were built with MEGA6.0, with 500 bootstrap replicates. Genetic diversity (Pi) of CVYV and gene flow, measured as Fst between Sudanese and other isolates were calculated with DNAsp (Rozas et al., 2003). Genetic differentiation was estimated with DNAsp using 3 permutation-based statistical tests (Hudson, 2000) as in Velasco et al., 2016.

\section{Full-length sequencing of CVYV isolates}

Isolate SU96-84 was selected for full-length genome sequencing, as well as 7 isolates from different origins: the original CVYV isolate from cucumber in Israel (Lecoq et al., 2000), isolates from Tunisia (TN05-56, collected in 2005 from zucchini, close to Monastir; Yakoubi et al., 2007), Oman (OM04-06, collected in 2004 from melon in Al Suwayq; Lecoq and AlMatrooshi, unpublished), Lebanon (LI97-11, collected in 1997 from cucumber in Jiyeh; Lecoq and Abou-Jawdah, unpublished), Iran (IR02-106; collected in 2002 from cucumber in Jiroft; Bananej et al., 2006), Spain (CVYV-Esp, collected in 2000 from melon; Pitrat et al., 2012), and a Sudanese isolate collected in 2012 from squash in Fadasi (SU12-10; Lecoq and Dafalla, unpublished). The samples were kept as dried infected plant tissues on calcium chloride, and were mechanically inoculated to melon, cucumber or zucchini squash for RNA extraction.

Total RNA from fresh or dried leaf samples was extracted using TRI-reagent. In order to obtain full-length sequences of CVYV isolates, RT-PCR were performed with "potyvirid" primers amplifying the $\mathrm{Cl}-\mathrm{NIb}$ and NIb-3'NC regions as described (Desbiez et al., 2017). For the $5^{\prime}$ half of the genome, primers were designed based on the available full-length

This article is protected by copyright. All rights reserved. 
sequences of CVYV (GenBank NC_006941, JF460793 and KT276369 for Spanish (ALM32), Jordanian (Jord-gp1) and Israeli (ISM) isolates. respectively), as well as a sequence of coccinia mottle virus (CocMoV), a newly described ipomovirus closely related to CVYV (KU935732; Desbiez et al., 2016). For isolate SU12-10, Illumina MiSeq high-throughput sequencing was performed on small RNAs (Fasteris, Switzerland). The fragments were assembled de novo with CLC Genomics Workbench 7 (CLC Bio, Aarhus, Denmark) and the sequence was completed by defining primers on the different contigs obtained, RT-PCR and Sanger sequencing.

Comparisons of full-length sequences and phylogenetic analyses

Sequences were assembled with CAP3 (Huang \& Madan, 1999) with manual corrections when needed. The best substitution model was selected with MEGA6 (Tamura et al., 2013). Nucleotide and deduced amino-acid sequences were aligned using ClustalW and MAFFT included in MEGA6. For divergent sequences, nucleotide alignments in the coding regions were performed based on amino-acid alignments. Percentages of identity ( $p$-distances) were calculated for whole sequences and for the different regions using MEGA6. Genetic comparisons were also performed including the 3 complete CVYV sequences available in GenBank (see above) and the complete sequences of CocMoV and SqVYV.

Recombination and selection analyses for CVYV

Eleven full-length or nearly full-length CVYV sequences, including the GenBank sequences of isolates ALM32, Jord-gp1 and ISM and the 8 sequences obtained during this work, were analysed for recombination using different methods implemented in RDP4 (Martin et al., 2015): RDP, GeneConv, MaxChi, Bootscan, SiScan and Chimaera. Only recombination signals

This article is protected by copyright. All rights reserved. 
detected by at least 5 methods and with a p-value of less than 0.001 were taken into consideration. The same dataset was analysed with GARD included in the HyPhy package (Kosakovsky Pond et al., 2005). Recombination signals were also analysed with SplitsTree (Kloepper\& Huson, 2008) on the alignment of the 11 CVYV sequences.

Selective pressures acting on CVYV genomes were estimated by calculating the $\mathrm{dN} / \mathrm{dS}$ ratio of nonsynonymous to synonymous mutation rates along the whole coding region of the genome, for the 11 complete coding sequences available. Search for positive selection (i.e. $\mathrm{dN} / \mathrm{dS}>1$ ) was performed with the FEL, MEME and FUBAR methods implemented on the HyPhy platform (www.datamonkey.org). The analyses were performed on the whole dataset in a first approach, then separately for the different fragments where no recombination signals were detected and for each protein.

Molecular clock analysis

A molecular clock test was performed on the 11 complete CVYV sequences available by comparing the maximum likelihood value for the given topology with and without the molecular clock constraints under Tamura (1992) model (+G) [1]. Differences in evolutionary rates among sites were modelled using a discrete Gamma (G) distribution. Codon positions included were 1st+2nd+3rd+Noncoding. Evolutionary analyses were conducted in MEGA 6.0 (Tamura et al., 2013).

Pairwise patristic distances between the sequences were calculated with PATRISTIC (Fourment \& Gibbs, 2006). For each node, the basal divergence corresponds to double the mean length of the individual branches linked through the node. The mutation fixation rate that has been estimated for potyviruses at circa $1.3 \times 10^{-4}$ nucleotides per site and per year

This article is protected by copyright. All rights reserved. 
(ns/s/yr) (Gibbs et al., 2008) was applied to the dataset in order to estimate the divergence time of the isolates.

Results

Biological properties of SU96-84

After mechanical inoculation SU96-84 infected systemically only cucurbits (melon, cucumber, zucchini squash and watermelon). No systemic infection was detected in 18 noncucurbit hosts belonging to 8 families (Table 1 ).

Relationships with the whitefly vector

Effect of length of acquisition access period. The two experiments run to test the effects of AAP on vector infectivity gave results not significantly different at the Chi-square test. The results were therefore pooled to give: $9 / 30,9 / 30,6 / 30,4 / 30,7 / 30,9 / 27,10 / 27$, and 10/27 (infected plants/tested) for $4,6,8,12,16,24,32$, and 48 h AAPs respectively, giving estimated probabilities of single vector infection of $0.023,0.035,0.044,0.028,0.052,0.078$, 0.088 , and 0.088 respectively. The results, summarized in Fig. 1a, indicate that the acquisition of CVYV from melon plants by $B$. tabaci is not a very efficient process, and that it takes about $8 \mathrm{~h}$ of acquisition access to reach half of the maximum attainable infectivity. Effect of length of inoculation access period (IAP). Infectivity reached a maximum at $15 \mathrm{~h}$ of IAP and did not change significantly afterwards. (Fig. 1b)

Retention of infectivity in the vector. Vectors infected test plants up to 12 but not $15 \mathrm{~h}$ after the end of $8 \mathrm{~h} \mathrm{AAP}$, both in the serial transfer and in the massive transmission test. (Supplementary Figure S1). The half-life of the virus in a feeding insect, or the time needed to reduce the infectivity to half its initial value, $t_{1 / 2}$, was $2 \mathrm{~h}$.

This article is protected by copyright. All rights reserved. 
Prevalence of CVYV in Sudan (DAS-ELISA + RT-PCR)

Out of the 422 samples from Sudan tested for the presence of CVYV, 100 were found positive. Positive samples were found between 1992 and 2012 on a $600 \mathrm{~km}$ area along the Nile River, from Kenana (300 km south of Khartoum) to Atbara (300 km north of Khartoum), mostly on melon or snake cucumber (Cucumis melo var. flexuosus) but also on watermelon, squash and zucchini, loofah and bitter gourd (Lagenaria siceraria) (supplementary table S2).

Diversity and genetic structure of CVYV populations in Sudan Including SU96-84 and SU12-10, Core CP sequences were obtained for 64 of the 100 CVYVpositive isolates collected in Sudan between 1992 and 2012 (supplementary table S2). The 36 remaining isolates were not sequenced, either because PCR amplification was too low, or because they were from sampling sites where several sequences were already available. Among the 64 sequences, eight isolates contained mixed infections with different variants (up to $5 \%$ double peaks in the sequence) and were removed from the analysis. All Sudanese isolates clustered in one clade very distinct from the other isolates from the Mediterranean Basin (Fig.2). Within the Sudanese isolates (accessions MK760929-982), two subgroups were defined with a high bootstrap support, without obvious relationship to the geographic origin of the isolates, original host or year of sampling (Fig.2). The genetic diversity of CVYV isolates within the Sudanese cluster $(\mathrm{Pi}=0.03643)$ was similar to the diversity between all other isolates from the Middle East and Mediterranean Basin ( $\mathrm{Pi}=0.03289)$. There was a strong genetic differentiation between the Sudanese and Mediterranean clusters, as indicated by a very high Fst value $(\mathrm{Fst}=0.675)$. Genetic differentiation estimated by 3 permutation-based methods was highly significant: $\mathrm{Ks}^{*}=2.35817 \mathrm{p}<10^{-4} ; \mathrm{Z}^{*}=6.056 \mathrm{p}<10^{-4}$; Snn $=1 p<10^{-4}$

This article is protected by copyright. All rights reserved. 
Full-length sequence of SU96-84 and worldwide isolates

Complete sequences of isolates CVYV-Esp from Spain, CVYV-ISR from Israel, TN05-56 from Tunisia, OM04-06 from Oman, LI97-11 from Lebanon, IR02-106 from Iran, SU96-84 and SU12-10 from Sudan were obtained (GenBank accessions MK777988-MK777995). All isolates had the typical CVYV genetic organization, with no helper component and a duplicated P1 protein (Valli et al., 2008). All CVYV sequences except SU96-84 and SU12-10 shared at least $93 \%$ nt identity (96\% aa identity), whereas SU96-84 and SU12-10 displayed only $83-85 \%$ nt identity (91-92\% aa identity) with the 9 isolates from the Mediterranean Basin and Middle East and between each other. The sequences from the Israeli isolate was very similar to that of the mild CVYV-ISM (probably originating from the same 1960 isolate but with different life history in the lab), with only 40 mutations along the whole genome (99.6\% identity). CVYV-Esp and the previously sequenced CVYV-ALM32 isolate from southern Spain also shared $99.7 \%$ identity. SU96-84 has a 54nt (18aa) deletion in the P1a coding region compared to all other isolates. No other indel was observed in the coding region of the CVYV full-length sequences, including in the variable $\mathrm{N}$-terminal part of the coat protein. The most variable parts of the genome appeared to be P1a and the small $6 \mathrm{~K} 2$ : up to $23 \%$ nt divergence $-29 \%$ aa divergence - between SU96-84 and the other isolates in $\mathrm{P} 1 \mathrm{a}$, and $24 \%$ nt $(24.5 \%$ aa) in $6 \mathrm{~K} 2$. Cleavage sites appeared conserved between isolates (data not shown). The P1b of all isolates contained the LxKA and putative Zinc-finger motifs present in CVYV P1b and involved in silencing suppression, as well as the Serine protease domain required for the protein self-cleavage (Valli et al., 2008).

This article is protected by copyright. All rights reserved. 
Recombination signals were detected with at least 5 of the methods implemented in RDP4 between the full-length sequences of isolates L197-11, Jord-gp1 and CVYV-Esp near positions 1500 ( $p=10^{-7}$ to $10^{-25}$ depending on the method), between isolates TN05-56, Jord-gp1 and CVYV-Esp or ALM32 ( $p=10^{-2}$ to $10^{-6}$ ) near position 1800 , and between SU96-84, SU12-10 and an unknown minor parent at position $8286\left(p=10^{-6}\right.$ to $\left.10^{-20}\right)$ in the dataset excluding the $5^{\prime}$ and $3^{\prime}$ non-coding $(\mathrm{NC})$ regions. Two significant recombination signals $(p<0.001)$ were found with GARD at positions 1521 and 2876. Using SplitsTree4, phylogenetic relationships between the 11 CVYV sequences appeared network-like, suggestive of recombination events (data not shown), and the phi-test for recombination was significant $\left(p=3.510^{-12}\right)$. In order to determine the parental and recombinant sequence(s), the same analyses were performed on the dataset excluding each of the putative recombinants one by one or two by two. Recombination signals were still detected with RDP4, GARD and SplitsTree when only one isolate was removed. Recombination signals disappeared with GARD when LI97-11 and TN05-56 were removed, and with all methods when LI97-11, TN05-56 and SU12-10 were removed simultaneously ( $p=0.37$ for SplitsTree Phi-test). This suggests that LI97-11 and TN05-56 are indeed recombinant isolate, and it is also probably the case for SU12-10.

\section{Selection pressure along CVYV genome}

The average $d N / d S$ ratio of nonsynonymous to synonymous mutations was 0.08 for the whole CVYV coding region, showing that the genome as a whole is under purifying selection. $\mathrm{dN} / \mathrm{dS}$ values for each protein ranged from 0.03 to 0.05 for the $\mathrm{Cl}, \mathrm{VPg}$, Nia-Pro, Nib and 6K1 regions, 0.07 for the $\mathrm{CP}, 0.1$ to 0.15 for $\mathrm{P} 1 \mathrm{~b}, \mathrm{P} 3$ and $6 \mathrm{~K} 2$, and 0.26 for the $\mathrm{P} 1$ a coding region, the most variable and least constrained region in the CVYV genome. Positive selection at the codon level was detected by FEL for 13 sites in the 5' half of the genome. Episodic diversifying selection was detected by MEME for 21 codons, 7 of which were common with

This article is protected by copyright. All rights reserved. 
those detected by FEL. Only codon 404, also detected by FEL and MEME, was found under positive selection with FUBAR. The biological meaning of such selection remains unknown so far.

Molecular clock analysis

The maximum likelihood values for a given topology for the 11 CVYV sequences available was compared with (In L $=-31458.116$ ) and without (In $L=-31446.284$ ) molecular clock constraints. The null hypothesis of equal evolutionary rate throughout the tree was not rejected at a $5 \%$ significance level $(P=0.166)$. The patristic distance between SU96-84 and the other isolates including SU12-10 was 0.2. Between SU12-10 and the Mediterranean Basin isolates, the distance was 0.17 to 0.18 . Between the Mediterranean Basin isolates, except for the closely related CVYV-ALM32/CVYV-Esp and CVYV-ISR/CVYV-ISM, the distance was 0.05 to 0.06 . By applying the potyvirus molecular clock rate of mutation fixation of $1.3 \mathrm{x}$ $10^{-4} \mathrm{~ns} / \mathrm{s} / \mathrm{yr}$, the divergence time of SU96-84 with the other isolates can be estimated to approximately 770 years, and $200-230$ years for the Mediterranean isolates.

\section{Discussion}

Previous studies on CVYV molecular variability suggested that the virus originated in the Middle East and spread throughout the Mediterranean Basin that constitutes its present geographic range (Velasco et al., 2016). Besides, we showed that CVYV was present in Sudan at least since 1992, and that Sudanese isolates are highly divergent molecularly from Mediterranean Basin isolates. The biological properties (host range and vector transmission properties) of the Sudanese isolate SU96-84 were very similar to those of CVYV isolates from Israel and Jordan (Harpaz \& Cohen, 1965); (Mansour \& Al-Musa, 1993). They confirm

This article is protected by copyright. All rights reserved. 
that the host range of CVYV is mostly restricted to cucurbits, and that its transmission by $B$. tabaci is semi-persistent, with a persistence in the vector of 9-12 hr. In spite of a limited host range and poorly efficient vector transmissibility, CVYV appeared to be frequent and widely spread in cucurbit crops in Sudan (detected in $24 \%$ of 422 isolates). This might be due to the fact that cucurbits are grown all year round, alternating rain-fed, irrigated and flood irrigated crops, providing constant virus and vector sources.

The molecular diversity of CVYV in Sudan isolates appears as high as the average diversity in all the other locations where the virus has been found. This suggest that CVYV has long been present in Sub-Saharan Africa with few genetic exchanges with Mediterranean populations of the virus. The frequency of CVYV in Sudan was high among cultivated cucurbits - almost $25 \%$ of the collected and tested samples - whereas the closely related CocMoV, transmitted by the same vector and infecting the same hosts in the lab, had a very low frequency in the same surveys and was found only twice in the perennial cucurbit weed Coccinia grandis (Desbiez et al., 2016). These contrasted situations could be related to different adaptation to the local biotype(s) of $B$. tabaci, and/or to the relative geographic isolation of the area where CocMoV was found. Although the center of origin of CVYV remains to be determined, particularly through deeper insights into its prevalence and phylogeography throughout Africa, it could be located in Eastern Africa, a center of diversification for melon and watermelon (Romay et al., 2014). However, as previously described, the direct origin of the currently emerging European isolates obviously lies in the Middle East/North African populations (Velasco et al., 2016) rather than Sub-Saharan ones. Analysis of 11 full-length CVYV sequences indicated the presence of recombination events in Mediterranean populations, and possibly among Sudanese populations. Phylogenetic discrepancies suggestive of recombination has been previously observed between the P1a, P3 and CP

This article is protected by copyright. All rights reserved. 
coding regions of Jordanian isolates (Velasco et al., 2016). In this work, recombination signals were detected in several isolates for which complete sequences were available, suggesting a rather high frequency of recombinants in Mediterranean CVYV populations, and possibly also in Sudanese ones.

These results show that the diversity and geographic range of CVYV are higher than previously expected, and that they must be taken into consideration in the design of control strategies against this virus, particularly those using resistance breeding (Pitrat et al., 2012, Galipienso et al., 2013).

\section{Acknowledgements}

We thank Drs Y. Abou-Jawdah, A. Al-Matrooshi and K. Bananej for their help in collecting the isolates used for this study. We thank the Experimental Infrastructure team of INRAMontfavet for their help in the greenhouse experiments, and the Microscopy Platform at INRA-Montfavet for the electron microscope observations.

The authors declare that they have no conflict of interest.

This article is protected by copyright. All rights reserved. 
References

Adkins S, Webb SE, Achor D, Roberts PD and Baker CA, 2007. Identification and characterization of a novel whitefly-transmitted member of the family Potyviridae isolated from cucurbits in Florida. Phytopathology, 97, 145-54.

Bananej K, Desbiez C, Girard M, Wipf-Scheibel C, Vahdat I, Kheyr-Pour A, Ahoonmanesh A, and Lecoq H, 2006. First report of Cucumber vein yellowing virus on Cucumber, Melon, and Watermelon in Iran. Plant Disease, 90, 1113.

Caciagli P, Bosco D and Al-Bitar L, 1995. Relationships of the Sardinian isolate of tomato yellow leaf curl geminivirus with its whitefly vector Bemisia tabaci Gen. European Journal of Plant Pathology, 101, 163-70.

Cohen S and Nitzany FE, 1960. A whitefly transmitted virus of cucurbits in Israel. Phytopathologia Mediterranea, 1, 44-6.

Cotillon A-C, Desbiez C, Bouyer S, Wipf-Scheibel C, Gros C, Delecolle B, and Lecoq H, 2005. Production of a polyclonal antiserum against the coat protein of Cucurbit yellow stunting disorder crinivirus expressed in Escherichia coli. Bulletin OEPP, 35, 99-103.

Cuadrado IM, Janssen D, Velasco L, Ruiz L and Segundo E, 2001. First report of Cucumber vein yellowing virus in Spain. Plant Disease, 85, 336.

Desbiez C, Delecolle B, Wipf-Scheibel C and Lecoq H, 2001. Le Cucumber vein yellowing virus, virus transmis par l'aleurode Bemisia tabaci, est un membre des Ipomovirus, Potyviridae. http://orian.u-strasbg.fr/aussois/RVV8_Aussois_2001.pdf Proceedings of the 8èmes Rencontres de virologie végétale, 2001. Aussois, France.

This article is protected by copyright. All rights reserved. 
Desbiez C, Verdin E, Tepfer M, Wipf-Scheibel C, Millot P, Dafalla G and Lecoq H, 2016. Characterization of a new cucurbit-infecting ipomovirus from Sudan. Archives of Virology, $161,2913-5$.

Desbiez C, Wipf-Scheibel C, Millot P, Verdin E, Dafalla G and Lecoq H, 2017. New species in the papaya ringspot virus cluster: Insights into the evolution of the PRSV lineage. Virus Research, 241, 88-94.

Fourment M and Gibbs MJ, 2006. PATRISTIC: a program for calculating patristic distances and graphically comparing the components of genetic change. BMC Evolutionary biology, 6 . Galipienso L, Janssen D, Rubio L, Aramburu J and Velasco L, 2013. Cucumber vein yellowing virus isolate-specific expression of symptoms and viral RNA accumulation in susceptible and resistant cucumber cultivars. Crop Protection, 43, 141-5.

Ghosh SK and Mukhopadhyay S, 1979. Viruses of pumpkin (Cucurbita moschata) in West Bengal. Phytopathologische Zeitschrift-Journal of Phytopathology, 94, 172-84.

Gibbs AJ, Ohshima K, Phillips MJ and Gibbs MJ, 2008. The prehistory of potyviruses: their initial radiation was during the dawn of agriculture. PLos One, 3, 1-11.

Gil-Salas FM, Colyer A, Boonham N, Cuadrado IM and Janssen D, 2009. Resistance screening against Cucumber vein yellowing virus using a real-time (Taqman) RT-PCR assay in cucumber (Cucumis sativus). Crop Protection, 28, 109-12.

Gil-Salas FM, Peters J, Boonham N, Cuadrado IM and Janssen D, 2012. Co-infection with Cucumber vein yellowing virus and Cucurbit yellow stunting disorder virus leading to synergism in cucumber. Plant Pathology, 61, 468-78.

Harpaz I and Cohen S, 1965. Semipersistent relationship between cucumber vein yellowing virus (CVYV) and its vector, the tobacco whiterly (Bemisia tabaci Gennadius). Phytopathologische Zeitschrift-Journal of Phytopathology, 54, 240-8.

This article is protected by copyright. All rights reserved. 
Huang X and Madan A, 1999. CAP3: A DNA sequence assembly program. Genome Research, 9, 868-77.

Janssen D, Martin G, Velasco L, Gomez P, Segundo E, Ruiz L and Cuadrado IM, 2005. Absence of coding region for the helper component-proteinase in the genome of cucumber vein yellowing virus, a whitefly-transmitted member of the Potyviridae. Archives of Virology, 150, 1439-1447.

Kloepper TH and Huson DH, 2008. Drawing explicit phylogenetic networks and their integration into SplitsTree. BMC Evolutionary biology, 8, 22.

Kosakovsky Pond SL, Frost SD and Muse SV, 2005. HyPhy: Hypothesis testing using phylogenies. Bioinformatics, 21, 676-9.

Lecoq H, Dafalla G, Delecolle B, Wipf-Scheibel C and Desbiez C, 2011. Snake melon asteroid mosaic virus, a tentative new member of the genus Sobemovirus infecting cucurbits. Plant Disease, 95, 153-7.

Lecoq H, Dafalla GA, Mohamed YF, Ali HM, Wipf-Scheibel C, Desbiez C, Eljack AE, Omara SK and Pitrat M, 1995. Survey of virus diseases infecting cucurbit crops in eastern, central and western Sudan. University of Khartoum Journal of Agricultural Sciences, 2.

Lecoq $\mathrm{H}$ and Desbiez C, 2012. Viruses of cucurbit crops in the mediterranean region: an ever-changing picture. Advances in Virus Research, 84, 67-126.

Lecoq H, Desbiez C, Delecolle B, Cohen S and Mansour A, 2000. Cytological and molecular evidence that the whitefly-transmitted Cucumber vein yellowing virus is a tentative member of the family Potyviridae. Journal of General Virology, 81, 2289-93.

Mansour A and Al-Musa A, 1993. Cucumber vein yellowing virus: host range and virus vector relationships. Journal of Phytopathogy, 137, 73-8.

This article is protected by copyright. All rights reserved. 
Martin DP, Murrell B, Golden M, Khoosal A and Muhire B, 2015. RDP4: Detection and analysis of recombination patterns in virus genomes. Virus Evolution, 1, 1-5.

Mohammed HS, Zicca S, Manglli A, Mohamed ME, El Siddig MA, Tomassoli L and El Hussein AA, 2014. Identification and phylogenetic analysis of common pumpkin viruses in Sudan. Journal of Plant Pathology, 96, 77-84.

Pitrat M, Wipf-Scheibel C, Besombes D, Desbiez C and Lecoq H, 2012. Resistance of melon to Cucumber Vein Yellowing Virus (CVYV). Cucurbitaceae 2012: Proceedings of the Xth Eucarpia Meeting on Genetics and Breeding of Cucurbitaceae, 157-64.

Reingold V, Lachman O, Sela N, Luria N and Dombrovsky A, 2016. Watermelon Fruit Rot Disease in Israel is Caused by a Distinct Squash vein yellowing virus (SqVYV) Strain. Plant Disease, 100, 1176-83.

Romay G, Lecoq H and Desbiez C, 2014. Cucurbit crops and their viral diseases in Latin America and the Caribbean Islands: a review. Journal of Plant Pathology, 96, 227-42.

Rozas J, Sanchez-Delbarrio JC, Messeguer X and Rozas R, 2003. DNAsp, DNA polymorphism analyses by the coalescent and other methods. Bioinformatics, 19, 2496-7.

Swallow WH, 1985. Group testing for estimating infection rates and probabilities of disease transmission. Phytopathology, 75, 882-9.

Tamura K, Stecher G, Peterson D, Filipski A and Kumar S, 2013. MEGA6: Molecular Evolutionary Genetics Analysis version 6.0. Molecular Biology and Evolution, 30, 2725-9.

Valli A, Dujovny G and Garcia JA, 2008. Protease activity, self interaction, and small interfering RNA binding of the silencing suppressor P1b from Cucumber vein yellowing ipomovirus. Journal of Virology, 82, 974-86.

This article is protected by copyright. All rights reserved. 
Velasco L, Salem N, Willemsen A, Lapidot M, Mansour AN, Rubio L and Galipienso L, 2016. Genetic variation and evolutionary forces shaping Cucumber vein yellowing virus populations: risk of emergence of virulent isolates in Europe. Plant Pathology, 65, 847-56.

Yakoubi S, Desbiez C, Fakhfakh H, Wipf-Scheibel C, Marrakchi M and Lecoq H, 2007. Occurrence of Cucurbit yellow stunting disorder virus and Cucumber vein yellowing virus in Tunisia. Journal of Plant Pathology, 89, 417-20.

Figure legends

Figure 1: Estimated probability $\left(\mathrm{p}^{\wedge}\right)$ for a single vector being infective (a) after different times of acquisition access (AAP), and (b) with different times of inoculation access (IAP) after $32 \mathrm{~h}$ AAP

Figure 2: distance tree based on a 439-nt fragment in the CVYV coat protein coding region for 56 Sudanese isolates and 17 isolates from the Mediterranean Basin and Middle East. Bootstrap values above $70 \%$ are indicated for each node. Isolates for which complete genome sequences are available are indicated in bold. The scale bar represents a genetic distance of 0.01 .

This article is protected by copyright. All rights reserved. 
Supplementary material:

Supplementary figure S1: Retention of CVYV infectivity by B. tabaci at different times after the end of acquisition access period (AAP)

Supplementary table S2: Host and geographic origin of the Sudanese isolates positive for CVYV

Table 1: Host range of CVYV isolate Su96 84.

\begin{tabular}{|l|l|}
\hline $\begin{array}{l}\text { Hosts systemically infected and } \\
\text { symptoms in brackets }\end{array}$ & $\begin{array}{l}\text { Citrullus lanatus var Sugar Baby }\left(\mathrm{M}^{1}\right), \text { Cucumis melo var } \\
\text { Védrantais }(\mathrm{VC}, \mathrm{M}), \text { Cucumis sativus var Beit alpha (severe } \\
\text { VC), Cucurbita pepo var F1 Diamant (slight VC) }\end{array}$ \\
\hline Hosts not systemically infected & $\begin{array}{l}\text { Capsella bursa-pastoris, Capsicum annuum var Yolo } \\
\text { Wonder, Chenopodium amaranticolor, C. quinoa, Datura } \\
\text { stramonium, Lactuca sativa } \text { var Trocadéro, Lavatera } \\
\text { trimestris, Nicotiana benthamiana, N. clevelandii, N. } \\
\text { tabacum } \text { var Xanthi, Ocimum basilicum, Petunia hybrida, } \\
\text { Phaseolus } \text { vulgaris var Pinto, Pisum sativum var Douce } \\
\text { Provence, Ranunculus sardous, Salvia splendens, Vigna } \\
\text { unguiculata, Zinnia elegans. }\end{array}$ \\
\hline
\end{tabular}

${ }^{1} \mathrm{M}$ : mottle, VC: vein clearing

This article is protected by copyright. All rights reserved. 


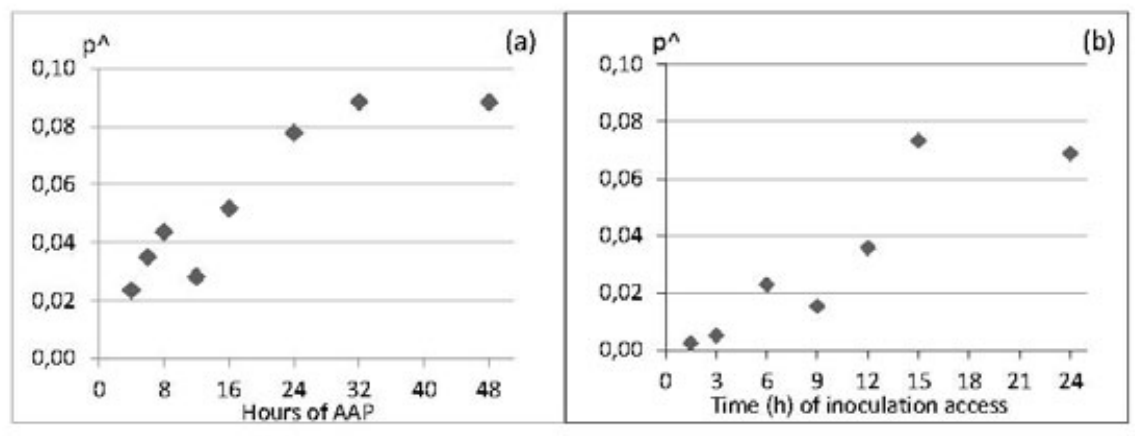

Figure 1

This article is protected by copyright. All rights reserved.

Desbiez, C. (Auteur de correspondance), Caciagli, P., Wipf-Scheibel, C., Millot, P., Ruiz, L. Marian, Dafalla, G., Lecoq, H. (2019). Evidence for longterm prevalence of cucumber vein yellowing virus in Sudan and genetic variation of the virus in Sudan and the Mediterranean Basin. 


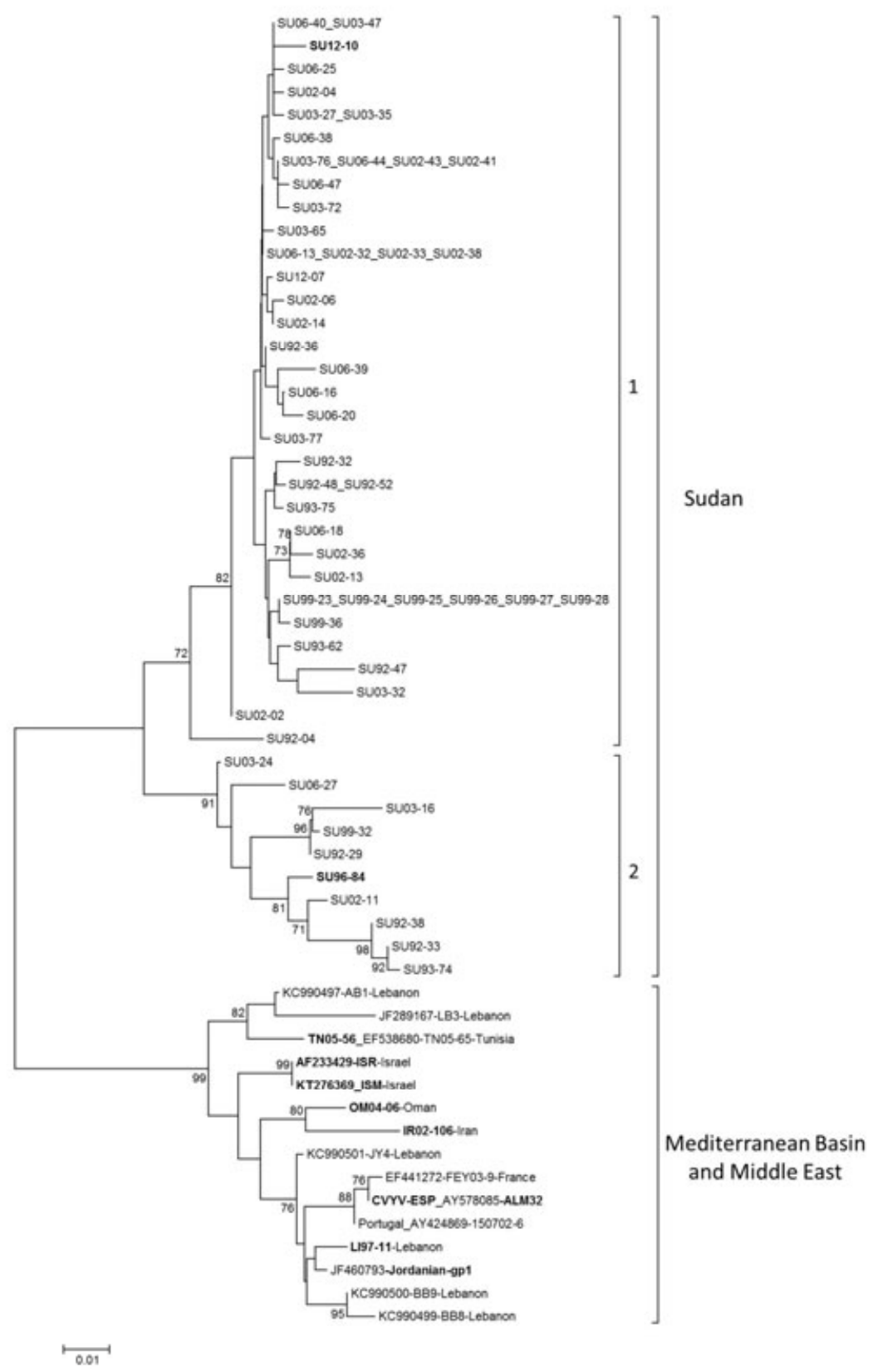

Figure 2

This article is protected by copyright. All rights reserved.

Desbiez, C. (Auteur de correspondance), Caciagli, P., Wipf-Scheibel, C., Millot, P., Ruiz, L.

Marian, Dafalla, G., Lecoq, H. (2019). Evidence for longterm prevalence of cucumber vein yellowing virus in Sudan and genetic variation of the virus in Sudan and the Mediterranean Basin. 